\title{
(2) OPEN ACCESS \\ Lumen-apposing metal stent placement for drainage of pancreatic fluid collections: predictors of adverse events
}

\author{
Ji Young Bang, ${ }^{1}$ Robert H Hawes, ${ }^{2}$ Shyam Varadarajulu (i) ${ }^{1}$
}

${ }^{1}$ Center for Interventional Endoscopy, AdventHealth Orlando, Orlando, Florida, USA ${ }^{2}$ AdventHealth Orlando, Orlando, Florida, USA

Correspondence to Dr Shyam Varadarajulu, Center for Interventional Endoscopy, AdventHealth Orlando, Orlando, FL 32803, USA:

svaradarajulu@yahoo.com

Received 23 December 2019 Revised 20 January 2020 Accepted 25 January 2020 Published Online First 17 February 2020

Check for updates

(C) Author(s) (or their employer(s)) 2020. Re-use permitted under CC BY-NC. No commercial re-use. See rights and permissions. Published by BMJ.

To cite: Bang JY, Hawes RH, Varadarajulu S. Gut 2020;69:1379-1381.

\section{MESSAGE}

Although rare in occurrence, adverse events such as delayed bleeding and buried stent syndrome have been reported after lumen-apposing metal stents (LAMS) placement in patients undergoing endoscopic ultrasound (EUS)-guided drainage of pancreatic fluid collections (PFCs). In a prospective study, we observed delayed adverse events in $6.4 \%$ of 188 patients which occurred when the PFCs were $7 \mathrm{~cm}$ or smaller in size and the removal of LAMS was delayed beyond 4 weeks.

\section{IN MORE DETAIL}

LAMS are being increasingly preferred over double pigtail plastic stents for patients undergoing EUSguided PFC drainage because their deployment is technically easy and the wide lumen facilitates quick drainage of cyst contents. However, delayed adverse events such as bleeding and buried stent syndrome have been reported after LAMS placement. ${ }^{1-3}$ In this study, we attempted to identify predictors of adverse events by examining data that were collected prospectively in all patients undergoing EUS-guided PFC drainage using LAMS. By institutional protocol, after LAMS placement, the endoprostheses were removed at outpatient follow-up in 3-4 weeks and all patients were contacted by telephone call to obtain follow-up at 6 months. The data collected included 292 demographic, laboratory, radiological, technical, clinical and treatment outcome variables, with a minimum follow-up duration of 6 months (NCT02422095).

Patient details, PFC characteristics, disease severity and clinical outcomes were summarised as means with SD and medians with IQR for continuous variables and as frequencies and proportions for categorical variables. In order to identify the factors associated with incidence of delayed adverse events after LAMS placement, multiple logistic regression and reverse stepwise multivariate logistic regression analyses were performed. Also, penalised logistic regression with Firth's correction was performed to identify the factors associated specifically with the incidence of delayed bleeding after LAMS placement. All clinically relevant variables including patient demographics, PFC characteristics, procedure details, LAMS indwelling time and disease severity were included as predictor variables. Datasets were compiled using Microsoft Excel (Microsoft, Richmond, Washington, USA), and all statistical analyses were performed using
Stata 14 (Stata, College Station, Texas, USA). Statistical significance was established as $\mathrm{p}<0.05$.

A total of 188 patients underwent EUS-guided drainage of PFCs (pseudocysts 31.4\%, necrotic collections 68.6\%) using LAMS over a 5 -year period between 2015 and 2019. Table 1 shows the patient demographics, preintervention PFC characteristics and disease severity of the study cohort. Adverse events were observed in 12 patients $(6.4 \%, 95 \% \mathrm{CI}$ $3.3 \%$ to $10.9 \%$ ) that included delayed bleeding in eight $(4.3 \%$, 95\% CI $1.9 \%$ to $8.2 \%)$ and buried stent syndrome in four $(2.1 \%, 95 \%$ CI $0.6 \%$ to $5.4 \%$ ) (figure 1). Bleeding was observed in a branch of the gastroduodenal artery or the splenic artery in five patients that were managed by interventional radiology-guided coil embolisation; mucosal bleeding was observed in three others that did not require further treatment. Buried stent syndrome was observed in the proximal stomach in four patients, which were successfully removed using endoscopic techniques in two patients. However, the stents could not be removed endoscopically in two patients as they were embedded in the deeper layers of the gastric wall and were referred for surgical removal.

The median time to adverse events after LAMS placement was 41 days (IQR 17-68), the majority $(\mathrm{n}=8,66.7 \%)$ due to non-compliance with timely follow-up. On multivariable logistic regression analysis, after adjusting for patient demographics, PFC characteristics, procedure details, LAMS indwelling time and disease severity, only stent removal after 4 weeks (OR 4.60, 95\% CI 1.30 to 16.3 , $\mathrm{p}=0.018)$ and PFC size of $\leq 7 \mathrm{~cm}$ in the anteroposterior dimension at computed tomogram (OR 4.33, $95 \%$ CI 1.10 to $17.0, \mathrm{p}=0.036$ ) were predictive of adverse outcomes (table 2). Importantly, the PFC size was specifically predictive of delayed bleeding (OR 42.4, 95\% CI 2.28 to $787.8, \mathrm{p}=0.012$ ).

\section{COMMENTS}

The present study demonstrates that adverse events can occur in up to $6 \%$ of patients undergoing EUS-guided drainage of PFCs using LAMS. This was observed when the endoprosthesis removal was delayed beyond 3-4 weeks when treating PFCs $<7 \mathrm{~cm}$ in size.

Unlike double pigtail plastic stents that tend to migrate out towards the gastrointestinal lumen when a PFC resolves, LAMS remain anchored in situ. It is postulated that the edges of the stent on persistent contact with vasculature adjacent to the 


\begin{tabular}{|c|c|c|}
\hline \multirow[t]{2}{*}{ Age (years) } & Mean (SD) & $53.6(14.2)$ \\
\hline & Median (IQR) & $55(43.5-64.5)$ \\
\hline \multirow[t]{2}{*}{ Gender: $\mathrm{n}(\%)$} & Female & $59(31.4)$ \\
\hline & Male & $129(68.6)$ \\
\hline \multirow[t]{3}{*}{ Race: n (\%) } & Black & $17(9.0)$ \\
\hline & White & $152(80.9)$ \\
\hline & Other & $19(10.1)$ \\
\hline \multirow[t]{4}{*}{ Cause of pancreatitis: $n(\%)$} & Gallstones & $39(20.7)$ \\
\hline & Alcohol & $75(39.9)$ \\
\hline & Idiopathic & $53(28.2)$ \\
\hline & Other* & $21(11.2)$ \\
\hline \multirow[t]{4}{*}{ Coexisting conditions: $\mathrm{n}(\%)$} & Cardiovascular disease & $23(12.2)$ \\
\hline & Pulmonary disease & $17(9.0)$ \\
\hline & Renal disease & $13(6.9)$ \\
\hline & Diabetes mellitus & $49(26.1)$ \\
\hline \multirow[t]{4}{*}{ ASA class: $\mathrm{n}(\%)$} & I & $13(6.9)$ \\
\hline & ॥ & $88(46.8)$ \\
\hline & III & $78(41.5)$ \\
\hline & IV & $9(4.8)$ \\
\hline \multirow[t]{3}{*}{ CT severity index: $n(\%)$} & $0-2$ & $32(17.0)$ \\
\hline & $4-6$ & $58(30.9)$ \\
\hline & $8-10$ & $98(52.1)$ \\
\hline \multirow{3}{*}{$\begin{array}{l}\text { Type of pancreatic fluid collection: } \\
n(\%)\end{array}$} & Pseudocyst & $59(31.4)$ \\
\hline & Acute necrotic collection & $18(9.6)$ \\
\hline & Walled-off necrosis & $111(59.0)$ \\
\hline \multirow{2}{*}{$\begin{array}{l}\text { Size of necrotic collection-AP axis } \\
(\mathrm{cm})\end{array}$} & Mean (SD) & $8.5(3.7)$ \\
\hline & Median (IQR) & $7.8(5.9-10)$ \\
\hline \multirow{2}{*}{$\begin{array}{l}\text { Size of necrotic collection- } \\
\text { transverse axis }(\mathrm{cm})\end{array}$} & Mean (SD) & $11.0(5.0)$ \\
\hline & Median (IQR) & $10(7-14)$ \\
\hline \multirow[t]{2}{*}{ Percentage of necrosis: (\%) } & Mean (SD) & $31.4(22.6)$ \\
\hline & Median (IQR) & $30(10-50)$ \\
\hline \multicolumn{2}{|c|}{ Collection extending to lower abdomen/pelvis: $n$ (\%) } & $36(19.1)$ \\
\hline \multirow[t]{2}{*}{ Disease severity: $\mathrm{n}(\%)$} & SIRS & $67(35.6)$ \\
\hline & ICU/high acuity care & $73(38.8)$ \\
\hline \multirow[t]{4}{*}{ Nutritional support: $\mathrm{n}(\%)$} & Enteral feeding & $38(20.2)$ \\
\hline & Parenteral feeding & $9(4.8)$ \\
\hline & Oral diet & $136(72.3)$ \\
\hline & Nil per os & $5(2.7)$ \\
\hline \multicolumn{2}{|c|}{ Percutaneous catheter in situ prior to intervention: $n$ (\%) } & $9(4.8)$ \\
\hline
\end{tabular}

*Other causes of PFC: Hypertriglyceridemia $(n=8)$, malignancy $(n=2)$, post-ERCP $(\mathrm{n}=2)$, post-trauma $(\mathrm{n}=9)$

AP, anteroposterior; ASA, American Society of Anesthesiologists; ICU, intensive care unit; SIRS, systemic inflammatory response syndrome.

PFC cavity can cause erosion of vessels precipitating a bleeding episode. Likewise, when a PFC resolves, the mucosal overgrowth can bury the endoprosthesis deep within the gastrointestinal wall layers causing buried stent syndrome. Based on the results of a recent randomised trial, it has been suggested that the LAMS should be removed within 3-4 weeks, provided the PFC has resolved. ${ }^{4}$ However, it has been unclear as to which patient is particularly risk-prone and therefore will require close observation and follow-up.

The present study demonstrates that when a PFC is $\leq 7 \mathrm{~cm}$ in size, it is likely that the cyst contents drain rapidly after LAMS placement. In these patients, if the LAMS is not removed within a 3-4 week time frame, adverse events such as buried stent syndrome and particularly, delayed bleeding may occur. Therefore, patients with PFC less than $7 \mathrm{~cm}$ in size should be scheduled

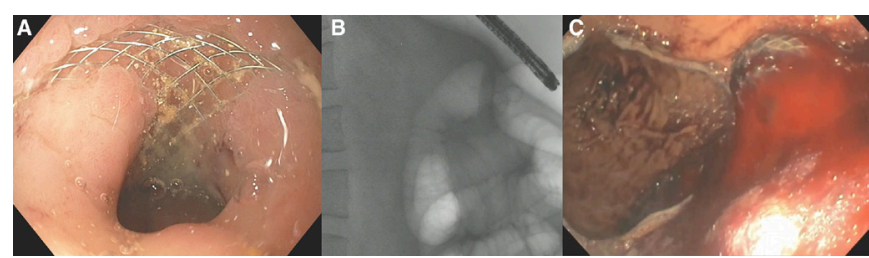

Figure 1 (A-C) Endoscopy view revealed mucosal overgrowth (A) over a buried LAMS, which was visualised at fluoroscopy (B). Endoscopic view of bleeding from LAMS (C). LAMS, lumen-apposing metal stents.

for follow-up imaging within 3-4 weeks and the LAMS must be removed in a timely manner if the fluid collection has resolved. Alternatively, small size PFCs may be treated using plastic stents in lieu of LAMS, particularly in patients with disconnected pancreatic duct syndrome who may benefit from an indwelling endoprosthesis to drain the upstream gland.

While the development of LAMS has significantly simplified the technique of PFC drainage and its utility for other applications such as gallbladder drainage, gastroenterostomy and biliary

Table 2 Multivariable logistic regression analysis examining factors associated with LAMS-associated adverse events

\begin{tabular}{|c|c|c|c|}
\hline Variable & OR & $95 \% \mathrm{Cl}$ & $P$ value \\
\hline \multicolumn{4}{|c|}{$\begin{array}{l}\text { Multiple logistic regression analysis: } \\
\text { Outcome variable=All LAMS-associated adverse events }\end{array}$} \\
\hline Age: $\geq 60$ vs $<60$ years & 1.23 & 0.33 to 4.63 & 0.762 \\
\hline Gender: Male vs Female & 0.91 & 0.24 to 3.49 & 0.888 \\
\hline Race: Caucasian vs Non-Caucasian & 0.96 & 0.18 to 5.28 & 0.966 \\
\hline $\begin{array}{l}\text { PFC type: Necrotic collection vs } \\
\text { Pseudocyst }\end{array}$ & 0.79 & 0.13 to 4.86 & 0.802 \\
\hline PFC size: $\leq 7 \mathrm{vs}>7 \mathrm{~cm}$ & 5.80 & 1.34 to 25.0 & 0.019 \\
\hline $\begin{array}{l}\text { PFC location: Tail involved vs Tail not } \\
\text { involved }\end{array}$ & 1.15 & 0.21 to 6.40 & 0.871 \\
\hline Degree of necrosis: $\leq 40$ vs $>40 \%$ & 1.52 & 0.30 to 7.61 & 0.608 \\
\hline $\begin{array}{l}\text { Route of drainage: Proximal stomach } \\
\text { vs Other }\end{array}$ & 1.95 & 0.37 to 10.3 & 0.431 \\
\hline CT severity index: $\geq 8 \mathrm{vs}<8$ & 1.07 & 0.18 to 6.20 & 0.943 \\
\hline ASA: III/IV vs I/II & 2.80 & 0.63 to 12.4 & 0.174 \\
\hline Time to LAMS removal: $>4$ vs $\leq 4$ weeks & 4.93 & 1.27 to 19.1 & 0.021 \\
\hline \multicolumn{4}{|c|}{$\begin{array}{l}\text { Reverse stepwise multivariate logistic regression analysis: } \\
\text { Outcome variable=All LAMS-associated adverse events }\end{array}$} \\
\hline PFC size: $\leq 7 \mathrm{vs}>7 \mathrm{~cm}$ & 4.33 & 1.10 to 17.0 & 0.036 \\
\hline Time to LAMS removal: $>4$ vs $\leq 4$ weeks & 4.60 & 1.30 to 16.3 & 0.018 \\
\hline \multicolumn{4}{|c|}{$\begin{array}{l}\text { Multiple penalised logistic regression with Firth's correction: } \\
\text { Outcome variable=LAMS associated bleeding only }\end{array}$} \\
\hline Age: $\geq 60$ vs $<60$ years & 1.14 & 0.24 to 5.37 & 0.866 \\
\hline Gender: Male vs Female & 0.34 & 0.07 to 1.74 & 0.197 \\
\hline Race: Caucasian vs Non-Caucasian & 11.1 & 0.32 to 382.9 & 0.182 \\
\hline $\begin{array}{l}\text { PFC type: Necrotic collection vs } \\
\text { Pseudocyst }\end{array}$ & 0.25 & 0.02 to 3.12 & 0.283 \\
\hline PFC size: $\leq 7 \mathrm{vs}>7 \mathrm{~cm}$ & 42.4 & 2.28 to 787.8 & 0.012 \\
\hline $\begin{array}{l}\text { PFC location: Tail involved vs Tail not } \\
\text { involved }\end{array}$ & 0.96 & 0.10 to 9.07 & 0.975 \\
\hline Degree of necrosis: $\leq 40$ vs $>40 \%$ & 1.25 & 0.23 to 6.83 & 0.795 \\
\hline $\begin{array}{l}\text { Route of drainage: Proximal stomach } \\
\text { vs Other }\end{array}$ & 5.76 & 0.79 to 41.9 & 0.084 \\
\hline CT severity index: $\geq 8$ vs $<8$ & 2.75 & 0.30 to 25.5 & 0.372 \\
\hline ASA: III/IV vs I/II & 3.35 & 0.56 to 20.1 & 0.186 \\
\hline Time to LAMS removal: $>4$ vs $\leq 4$ weeks & 1.54 & 0.35 to 6.78 & 0.566 \\
\hline
\end{tabular}

ASA, American Society of Anesthesiologists; LAMS, lumen-apposing metal stent; PFC, pancreatic fluid collection. 
bypass continues to evolve, a better understanding of the functionality and safety profile of the device is warranted. We believe that the observations detailed in this newsletter helps bridge some aspects of this knowledge gap.

Contributors JYB: study design, endoscopist performing procedures in the study, statistical analysis, interpretation of data, drafting of manuscript, critical revision of manuscript. SV: study concept and design, endoscopist performing procedures in the study, interpretation of data and drafting of manuscript and critical revision of manuscript. RH: endoscopist performing procedures in the study and critical revision of manuscript.

Funding The authors have not declared a specific grant for this research from any funding agency in the public, commercial or not-for-profit sectors.

Competing interests JYB: Consultant for Olympus America Inc. and Boston Scientific Corporation. SV: Consultant for Boston Scientific Corp., Olympus America Inc., Covidien and Creo Medical. RH: Consultant for Boston Scientific Corp., Olympus America Inc., Covidien, Creo Medical, Nine Points Medical and Cook Medical.

Patient consent for publication Not required.

Ethics approval Institutional Review Board approval number 1108594.

Provenance and peer review Not commissioned; internally peer reviewed.
Open access This is an open access article distributed in accordance with the Creative Commons Attribution Non Commercial (CC BY-NC 4.0) license, which permits others to distribute, remix, adapt, build upon this work non-commercially, and license their derivative works on different terms, provided the original work is properly cited, appropriate credit is given, any changes made indicated, and the use is non-commercial. See: http://creativecommons.org/licenses/by-nc/4.0/.

\section{ORCID iD}

Shyam Varadarajulu http://orcid.org/0000-0002-0047-0016

\section{REFERENCES}

1 Bang JY, Hasan M, Navaneethan U, et al. Lumen-apposing metal stents (LAMS) for pancreatic fluid collection (PFC) drainage: may not be business as usual. Gut 2017:66:2054-6.

2 Brimhall B, Han S, Tatman PD, et al. Increased incidence of pseudoaneurysm bleeding with lumen-apposing metal stents compared to double-pigtail plastic stents in patients with peripancreatic fluid collections. Clin Gastroenterol Hepatol 2018;16:1521-8.

3 Wang Z, Zhao S, Meng Q, et al. Comparison of three different stents for endoscopic ultrasound-guided drainage of pancreatic fluid collection: a large retrospective study. J Gastroenterol Hepatol 2019:34:791-8.

4 Bang JY, Navaneethan U, Hasan MK, et al. Non-superiority of lumen-apposing metal stents over plastic stents for drainage of walled-off necrosis in a randomised trial. Gut 2019;68:1200-9. 